AperTO - Archivio Istituzionale Open Access dell'Università di Torino

\title{
Atopic dermatitis in a phenylketonuric untreated patient
}

\section{This is the author's manuscript}

Original Citation:

Availability:

This version is available http://hdl.handle.net/2318/156436

since

Published version:

DOI:10.1111/ijd.12043

Terms of use:

Open Access

Anyone can freely access the full text of works made available as "Open Access". Works made available under a Creative Commons license can be used according to the terms and conditions of said license. Use of all other works requires consent of the right holder (author or publisher) if not exempted from copyright protection by the applicable law. 


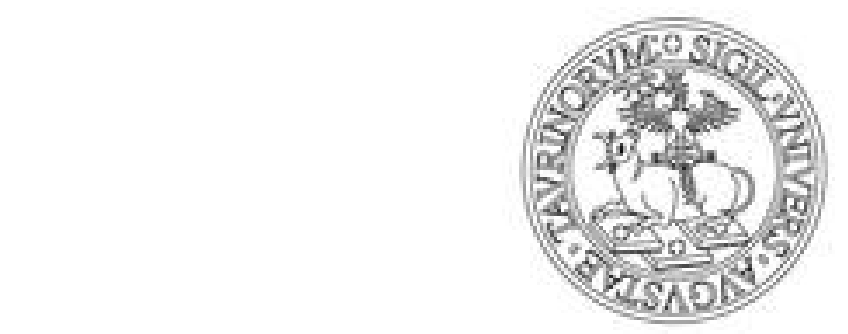

\section{UNIVERSITÀ DEGLI STUDI DI TORINO}

This is an author version of the contribution published on:

Fava p, Fierro MT, Brizio M, Marra E, Spada M, Bernengo MG

Atopic dermatitis in a phenylketonuric untreated patient

INTERNATIONAL JOURNAL OF DERMATOLOGY (2013) [Epub ahead of print]

DOI: $10.1111 / \mathrm{ijd} .12043$ 
Int J Dermatol. 2013 Jun 20. doi: 10.1111/ijd.12043.

Case report

\section{Atopic dermatitis in a phenylketonuric untreated patient}

Paolo Fava1, MD, Maria Teresa Fierro1, MD, Matteo Brizio1, MD, Elena Marra1, MD, Marco Spada2, MD, and Maria Grazia Bernengo1, MD

1 Department of Biomedical Sciences and Human Oncology, Section of Dermatology, University of Turin, Turin, Italy,

2 Department of Pediatric and Adolescence Sciences, University of Turin, Turin, Italy

\section{Correspondence}

Maria Teresa Fierro, MD Department of Medical Sciences Section of Dermatology, University of Turin v.

Cherasco 23, 10126, Torino, Italy E-mail: mariateresa.fierro@unito.it

Conflicts of interest: None.

doi: $10.1111 / \mathrm{ijd} .12043$

Phenylketonuria (PKU) is an autosomal recessive metabolic disease, which is seen in approximately 1:12,000-1:18,000 newborn.1,2 PKU results from a deficiency of phenylalanine hydroxylase, the enzyme converting phenylalanine into tyrosine. Hyperphenylalaninemia is the biochemical hallmark of PKU. Classic phenylketonuria is caused by a complete or near-complete deficiency of phenylalanine hydroxylase activity; 3 without dietary restriction of phenylalanine, patients will develop profound and irreversible intellectual disability and neurological disturbances. 2 The natural history of this disorder has been changed since newborn screening was introduced in the late 1960s, and affected children are now maintained on a phenylalanine restricted diet, which must commence as soon as possible after birth and should continue for life.4,5 Skin disorders linked with PKU are principally scleroderma-like changes with guttate or generalized morphea and hypopigmentation; dermatitis is also described in these patients.6-10 An accurate description of clinical features of this dermatitis cannot be found in the literature, and the relationship with atopic dermatitis, a multifactorial, inflammatory skin disease with a chronic or relapsing course, has never been analyzed thoroughly.11-13

\section{Case report}

We report the case of a 44-year-old Caucasian man with PKU complicated with atopic dermatitis referred to our institution for the worsening of erythematous areas of white scales, crusts, and multiple scratching lesions located at forearms, shoulders, inferior limbs, and sacral region (Figs. 1a and 2a). The Fitzpatrick phototype was I. Personal history revealed PKU first diagnosed at eight years old; PKU was not recognized in the neonatal period, thus the patient had a free diet that resulted in a permanent mental handicap. In addition, after PKU diagnosis, adhesion to dietary restriction was poor because of low family compliance. Since childhood, the patient has suffered from dermatitis with chronic pruritus and frequent infectious episodes, which has been diagnosed as atopic dermatitis and treated for years with topical steroids. Previous patch tests (with the European Standard Series of haptens) were negative. Biochemistry revealed leukocytosis (white blood cell count 10.349 109/L) with eosinophilia (13\%; absolute count: 1.879 109/L) and elevation of IgE levels (4145 kUI/L); plasma phenylalanine concentration was $1250 \mathrm{lmol} / \mathrm{L}$ (normal values lower than $120 \mathrm{Imol} / \mathrm{L}$ ); flow cytometry on peripheral blood lymphocytes failed to document an imbalance between different T-cell populations. Skin culture on lesions identified a non-MRSA Staphylococcus aureus. Histological findings were nonspecific, showing spongiosis, acanthosis, 
hyperkeratosis, and increased number of dermal lymphocytes (Fig. 3). The patient was treated with IV steroids (IV methylprednisolone $0.5 \mathrm{mg} / \mathrm{kg}$ daily), azithromycin, and topical tacrolimus. A strict, low phenylalanine diet was started with a phenylalanine intake not exceeding $400 \mathrm{mg} /$ day. IV steroid was tapered, and the patient was discharged with topical tacrolimus and dietary treatment only. Owing to good compliance with the diet, the plasma phenylalanine concentration dropped to $450 \mathrm{lmol} / \mathrm{L}$ in one month; tacrolimus was stopped one month later. After six months of dietary treatment, we observed an almost complete cutaneous response with regression of erythematous lesions and itching (Figs. $1 \mathrm{~b}$ and $2 \mathrm{~b}$ ), together with a reduction of IgE $(2712 \mathrm{kUI} / \mathrm{L})$ and eosinophil value $(0.79109 / \mathrm{L})$. This case could be considered as a PKU-related eczema but also a true extrinsic atopic dermatitis. Its peculiarity is represented by the surprising long-lasting clinical response to the dietary regimen. The report by Riva et al. demonstrates that IgE levels are higher in patients with PKU than in the normal population and suggests that a dietary regimen can control the development of immunoallergic signs and symptoms.11

Our report confirms that dietary regimen could not only avoid mental retardation in childhood but also reduce the incidence of cutaneous manifestations in PKU. This evidence can also provide an explanation to the reduced incidence of eczema in the patient with PKU observed in the last years.

\section{References}

1 Smith I, Cook B, Beasley M. Review of neonatal screening programme for phenylketonuria. Br Med J 1991; 303: 333-335.

2 Walter JH. Late effects of phenylketonuria. Arch Dis Childh 1995; 73: 485-486.

3 Scriver CR, Clow CR. Phenylketonuria: epitome of human biochemical genetics. N Engl J Med 1980; 303: 1336-1342.

4 Williams RA, Mamotte CD, Burnett JR. Phenylketonuria: an inborn error of phenylalanine metabolism. Clin Biochem Rev 2008; 29: 31-41.

5 Longo N, Ernst S. Management of phenylketonuria. US Pediatr 2008; 4: 59-62.

6 Foti R, Leonardi R, Rondinone R, et al. Scleroderma-like disorders. Autoimmunity Rev 2008; 7: 331-339.

7 Guillet G, Dore N, Hehunstre J, et al. Pseudoscleroderma and phenylketonuria. Int J Dermatol 1983; 22: 422-426.

8 Al-Mayouf SM, Al-Owain MA. Progressive sclerodermatous skin changes in a child with phenylketonuria. Pediatr Dermatol 2006; 23: 136-138.

9 Fistarol SK, Itin PH. Disorders of pigmentation. J Dtsch Dermatol Ges 2010; 8: 187-201.

10 Belloso LM, Lowitt MH. Cutaneous findings in a 51- year-old man with phenylketonuria. J Am Acad Dermatol 2003; 49: S190-S192.

11 Riva E, Fiocchi A, Agostoni C, et al. PKU-related dysgammaglobulinaemia: the effect of diet therapy on IgE and allergic sensitization. J Inherit Metab Dis 1994; 17: 710-717.

12 De Benedetto A, Agnihothri R, McGirt LY, et al. Atopic dermatitis: a disease caused by innate immune defects? J Invest Dermatol 2009; 129: 14-30.

13 Fisch RO, Tsai MY, Gentry WC Jr. Studies of phenylketonurics with dermatitis. J Am Acad Dermatol 1981; 4: 284-290. 

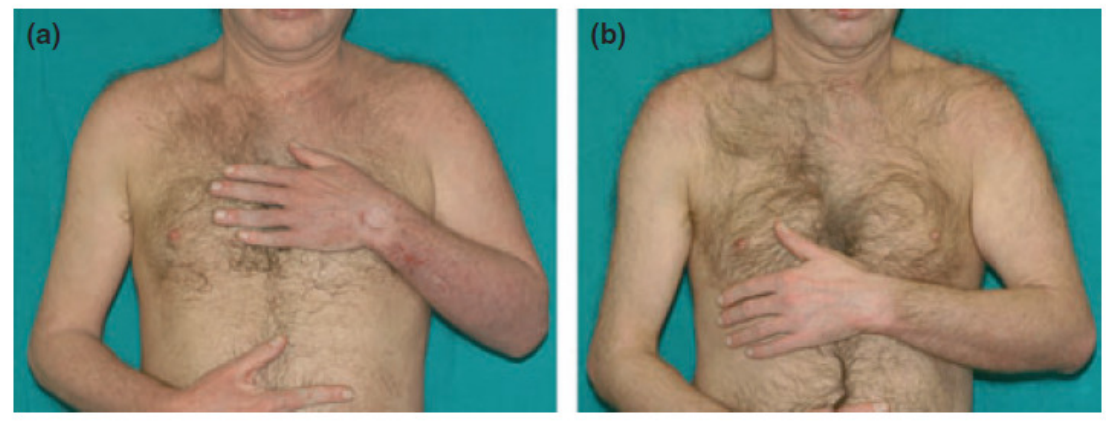

Figure 1 Clinical picture of the patient before (a) and 6 months after (b) phenylalanine-restricted diet
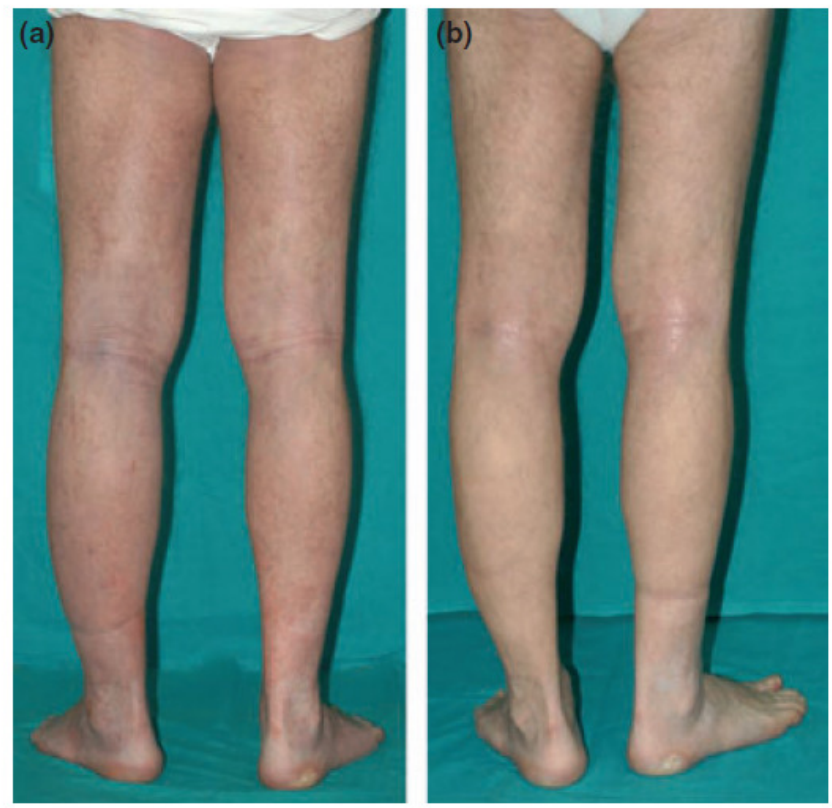

Figure 2 Clinical picture of the patient before (a) and 6 months after (b) phenylalanine-restricted diet

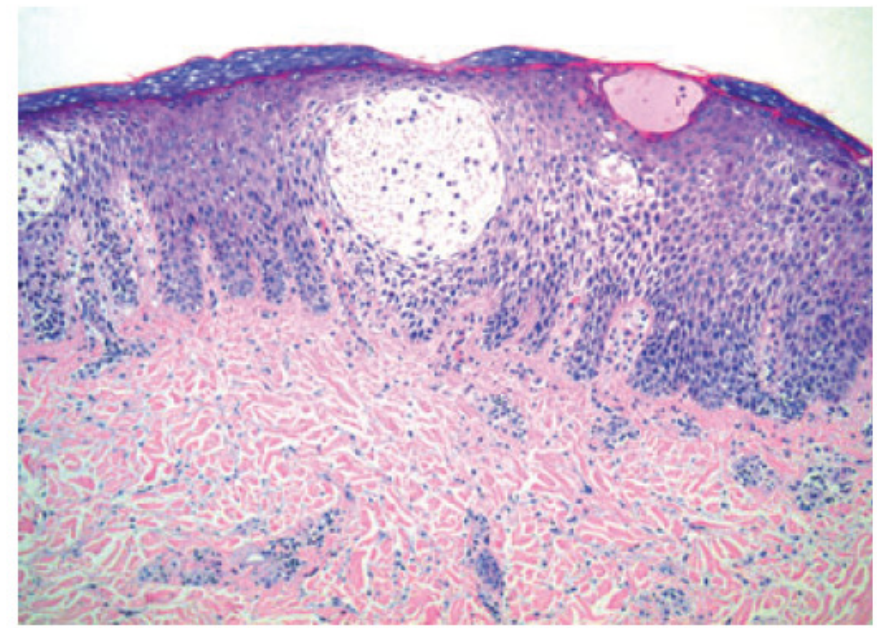

Figure 3 Skin biopsy shows spongiosis, acanthosis, hyperkeratosis, and increased number of dermal lymphocytes (hematoxylin and eosin, 9100) 